\title{
A case of rectal ulcers during aspirin therapy in acute Kawasaki disease
}

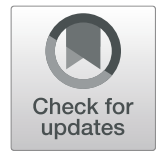

\author{
Yong Han, Chenmin Hu and Yanping Yu (D)
}

\begin{abstract}
Kawasaki disease (KD) is an acute febrile multisystem vasculitis and has been recognized to be one of the most common causes of acquired heart disease in children. Although gastrointestinal symptoms including vomiting, diarrhea, and abdominal pain are not uncommon in KD patients, KD with lower gastrointestinal bleeding is quite rare. Here, we describe a 3-year-old boy with typical KD who had lower gastrointestinal bleeding caused by rectal ulcers on the third day of aspirin therapy.
\end{abstract}

Keywords: Kawasaki disease, Gastrointestinal hemorrhage, Rectal ulcer, Aspirin

\section{Dear Editor,}

Kawasaki disease (KD) is a febrile multisystem vasculitis of unknown etiology, especially involving coronary arteries. Although the prevalence of gastrointestinal involvement in $\mathrm{KD}$ is unknown, gastrointestinal symptoms including vomiting, diarrhea, and abdominal pain are relatively common. However, KD with lower gastrointestinal bleeding is quite rare. Here, we describe a 3-yearold boy with typical KD who had lower gastrointestinal bleeding caused by rectal ulcers on the third day of aspirin therapy.

A 3-year-old boy was first seen on day 2 of high fever. On physical examination, enlarged tonsil, pharyngeal hyperemia, and coarse respiratory sounds of both lungs were noted. No other abnormal finding was present at that time. Laboratory findings were as follows: white blood cell count $14.8^{*} 10^{\wedge} 9 /$ $\mathrm{L}$, neutrophil $84.8 \%$, hemoglobin $131 \mathrm{~g} / \mathrm{L}$, platelet count $228 * 10^{\wedge} 9 / \mathrm{L}, \mathrm{C}$-reactive protein $122 \mathrm{mg} / \mathrm{L}$. He was admitted and treated with intravenous antibiotics empirically. The boy remained febrile. Three day later (day 5), the onset of maculopapular rash on the trunk and limbs, nonexudative conjunctivitis, strawberry tongue, edema of hands and feet, and an enlarged right cervical lymph node led to the

\footnotetext{
*Correspondence: yyp757605@163.com

Department of Pediatrics, Affiliated Hangzhou First People's Hospital,

Zhejiang University School of Medicine, Hangzhou, China
}

diagnosis of KD. Fortunately, echocardiography (Fig. 1A1, A2 )revealed no dilatation of coronary arteries $(2.2 \mathrm{~mm}$ left and $2.0 \mathrm{~mm}$ right). Then, intravenous immunoglobulin (IVIG, $2 \mathrm{~g} / \mathrm{kg}$ ) and oral aspirin $(50 \mathrm{mg} / \mathrm{kg}$ per day) were administered. After IVIG, his fever resolved rapidly. However, hematochezia occurred on day 3 of aspirin. Repeated laboratory examinations revealed white blood cell count of $7.1 \times$ $10^{\wedge} 9 / \mathrm{L}$ with predominance of neutrophil $51.2 \%$, hemoglobin level of $118 \mathrm{~g} / \mathrm{L}$, platelet count of $378 \times 10^{\wedge} 9 / \mathrm{L}$, and Creactive protein of $57 \mathrm{mg} / \mathrm{L}$. Colonoscopy revealed multiple superficial active ulcers in the rectum (Fig. 1B). Microscopic examination of a specimen from rectal biopsy revealed focal active colitis. There was predominantly neutrophilic infiltration within the lamina propria along with hemorrhage and crypt abscess formation (Fig. 1C). Thus, high-dose aspirin was stopped and intravenous methylprednisolone $(30 \mathrm{mg}$ per day) was given. Three days later, bloody stool disappeared. The intravenous methylprednisolone was changed to methylprednisolone tablets with gradually decreased dosage. Simultaneously, low-dose aspirin ( $4 \mathrm{mg} / \mathrm{kg}$ per day) was started. On day 15 , most of the laboratory parameters were normal except for elevated platelet count of $623 \times 10^{\wedge} 9 / \mathrm{L}$. The next day, he was discharged and continued with lowdose aspirin $(4 \mathrm{mg} / \mathrm{kg}$ per day) for 8 weeks. Further followup showed that the patient recovered without sequelae. 


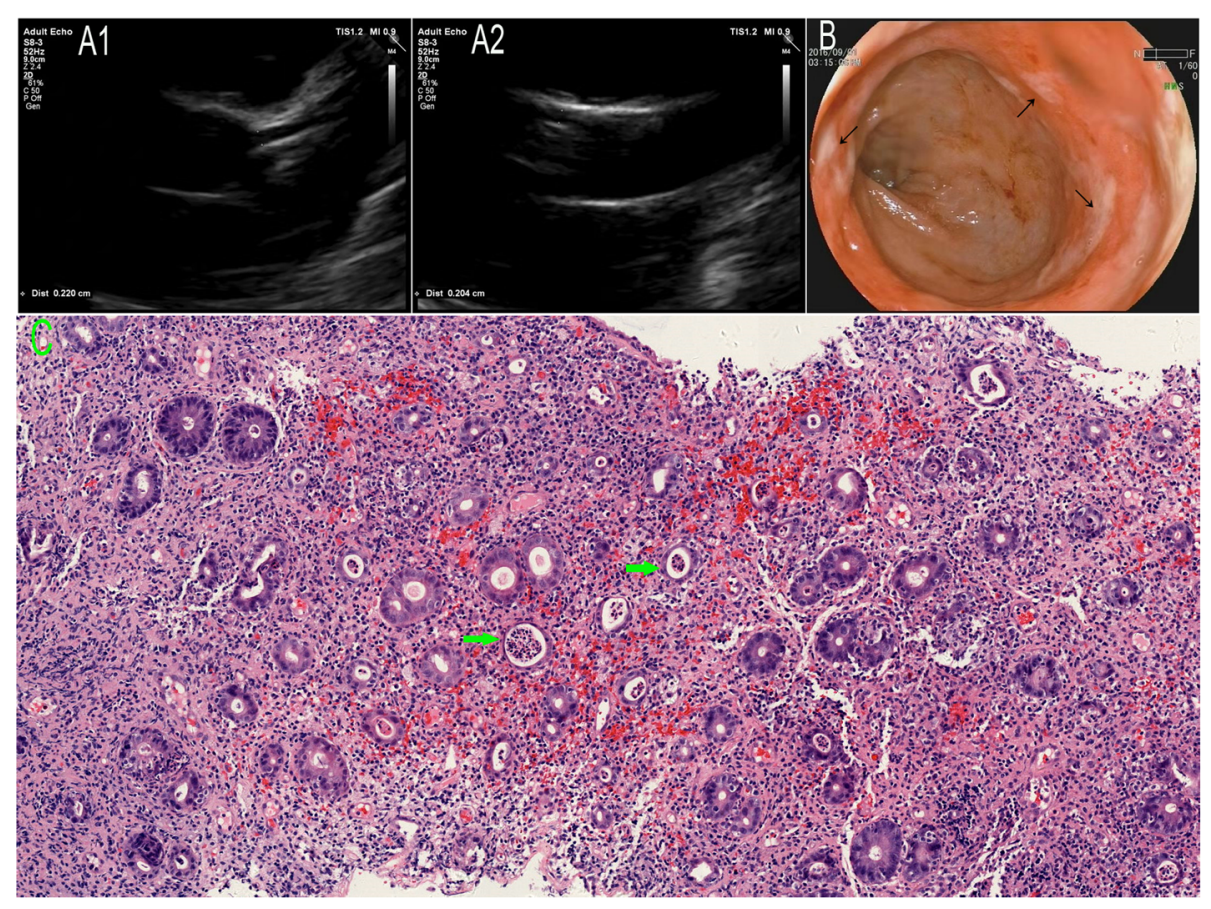

Fig. 1 A, Echocardiography shows no dilatation of left coronary artery (A1) and right coronary artery (A2). B, Colonoscopy results showing multiple superficial active ulcers covered with thick "white moss" in rectum. C, Histologic examination of biopsy shows prominent neutrophilic infiltration within the lamina propria along with hemorrhage and crypt abscess formation (green arrow), indicating focal active colitis (hematoxylin-eosin, magnification $\times 100)$

Only 5 cases of KD with gastrointestinal hemorrhage have been previously documented in the English literature (Table 1). Two cases with upper gastrointestinal bleeding occurred before the use of aspirin [1,2]. Three cases of upper gastrointestinal hemorrhage complicating highdose aspirin therapy might be iatrogenic [3, 4]. Adverse effects of nonsteroidal anti-inflammatory drugs (NSAIDs) on the lower gastrointestinal tract are also common; however, symptomatic NSAID-induced colitis is rare. Usually, histologically, there is no predominant cell type producing infiltration in colitis associated with NSAIDs [5]. Although the duration of exposure to NSAIDs before the development of symptoms of colitis is variable; most of the patients with NSAID-induced colitis have been taking these

Table 1 Clinical characteristics of the reported patients with gastrointestinal hemorrhage in Kawasaki disease

\begin{tabular}{|c|c|c|c|c|c|c|c|}
\hline Ref & $\begin{array}{l}\text { First } \\
\text { author }\end{array}$ & $\begin{array}{l}\text { Age/ } \\
\text { sex }\end{array}$ & Clinical onset & $\begin{array}{l}\text { Details of gastrointestinal } \\
\text { bleeding }\end{array}$ & $\begin{array}{l}\text { Blood } \\
\text { transfusion }\end{array}$ & Endoscopy & Surgery \\
\hline 1 & Zulian & $\begin{array}{l}20 \\
\mathrm{~m} / \mathrm{M}\end{array}$ & Fever & $\begin{array}{l}\text { Hematemesis on day } 7 \text { of } \\
\text { illness without aspirin }\end{array}$ & Yes & $\begin{array}{l}\text { Showed diffuse } \\
\text { hemorrhagic duodenitis }\end{array}$ & None \\
\hline 2 & Singh & $\begin{array}{l}4.5 y / \\
M\end{array}$ & $\begin{array}{l}\text { Nausea, vomiting, } \\
\text { diarrhea and fever }\end{array}$ & $\begin{array}{l}\text { Hemorrhagic shock with } \\
\text { hematemesis and hematochezia } \\
\text { at } 2 \text { months after onset } \\
\text { (without aspirin) }\end{array}$ & Yes & $\begin{array}{l}\text { Failed because of the } \\
\text { massive bleeding }\end{array}$ & $\begin{array}{l}\text { Revaeled a } 1.5 \mathrm{~cm} \\
\text { duodenal ulcer with } \\
\text { active bleeding }\end{array}$ \\
\hline \multirow[t]{2}{*}{3} & Matsubara & $\begin{array}{l}2 y / \\
M\end{array}$ & Fever & $\begin{array}{l}\text { Hematemesis on day } 19 \text { of } \\
\text { illness (day } 13 \text { of aspirin) }\end{array}$ & Yes & $\begin{array}{l}\text { Revealed a } 2 \mathrm{~cm} \\
\text { duodenal ulcer }\end{array}$ & None \\
\hline & & $4 \mathrm{y} / \mathrm{F}$ & Fever & $\begin{array}{l}\text { Melanotic stools followed by } \\
\text { emesis of blood on day } 31 \text { of } \\
\text { illness (day } 26 \text { of aspirin) }\end{array}$ & Yes & None & None \\
\hline 4 & Chang & $\begin{array}{l}5 y / \\
M\end{array}$ & $\begin{array}{l}\text { Fever, cervical } \\
\text { lymphadenitis }\end{array}$ & $\begin{array}{l}\text { Tarry stool on day } 6 \text { of illness; } \\
\text { Massive gastrointestinal } \\
\text { bleeding on day } 14 \text { of illness } \\
\text { (day } 5 \text { of aspirin) }\end{array}$ & Yes & NA & NA \\
\hline
\end{tabular}


drugs for more than 6 months [6]. Our patient developed lower gastrointestinal bleeding on day 3 of aspirin, due to active rectal ulcers. Histological examination of a colonoscopic biopsy specimen revealed prominent neutrophilic infiltration and crypt abscess formation, indicating focal active colitis. In light of clinical details and histological features, we suspect that aspirin may not be the primary cause of rectal ulcers in our patient. Vasculitis of the submucosal artery in the rectum together with the local pathogens might play an important role. Undoubtedly, we can not rule out that high-dose aspirin may play a promoting role. As a matter of fact, the role of high-dose aspirin in KD remains controversial. Kuo et al. [7] demonstrated that high-dose aspirin in KD did not confer any benefit with regards to inflammation and it did not appear to improve treatment outcomes. A recent meta-analysis revealed that low-dose aspirin $(3-5 \mathrm{mg} / \mathrm{kg} / \mathrm{d})$ may be as effective as the use of high-dose aspirin $(>30 \mathrm{mg} / \mathrm{kg} / \mathrm{d})$ for the initial treatment of KD [8]. In summary, pediatricians should be aware of the risk of gastrointestinal bleeding in $\mathrm{KD}$ children, especially in those receiving high-dose aspirin.

\section{Abbreviations}

IVIG: Intravenous immunoglobulin; KD: Kawasaki disease

\section{Acknowledgements}

We are grateful to Zhejiang Medical and Health Science and Technology Plan for establishing the project (2019321962/2019KY485), although there is no funding.

\section{Authors' contributions}

YH collected and interpreted the patient data and was a major contributor in revising the manuscript. $\mathrm{CH}$ collected literatures and was a contributor in drafting the manuscript. YY designed the work and drafted the manuscript. All authors read and approved the final manuscript.

\section{Funding}

This work did not receive funding.

\section{Availability of data and materials}

The datasets used and/or analyzed during the current study are available from the corresponding author on reasonable request.

\section{Ethics approval and consent to participate}

The study protocol was approved by the Ethics Commission of Affiliated Hangzhou First People's Hospital, Zhejiang University School of Medicine. Permission to carry out the study and access patient records was sought from the respective hospital administrators.

\section{Consent for publication}

Written consent for publication of this anonymous information was obtained from the patient's parents and the proof of consent can be requested at any time.

\section{Competing interests}

The authors declare that they have no competing interests.
Received: 5 October 2019 Accepted: 2 March 2020

Published online: 17 March 2020

References

1. Zulian F, Falcini F, Zancan L, Martini G, Secchieri S, Luzzatto C, et al. Acute surgical abdomen as presenting manifestation of Kawasaki disease. J Pediatr. 2003;142:731-5.

2. Singh R, Ward C, Walton M, Persad R. Atypical Kawasaki disease and gastrointestinal manifestations. Paediatr Child Health. 2007;12:235-7.

3. Matsubara T, Mason W, Kashani IA, Kligerman M, Burns JC. Gastrointestinal hemorrhage complicating aspirin therapy in acute Kawasaki disease. J Pediatr. 1996;128:701-3.

4. Chang $\mathrm{CH}$, Chen $\mathrm{MH}$, Yang W. Kawasaki disease presenting with lymphadenopathy and gastrointestinal hemorrhage: report of one case. Acta Paediatr Taiwan. 2004:45:171-3.

5. Sherid M, Ehrenpreis ED. Types of colitis based on histology. Dis Mon. 2011; 57:457-89.

6. Shibuya T, Ohkusa T, Yokoyama T, Harada A, Beppu K, Sakamoto N, et al. Colonic mucosal lesions associated with long-term or short-term administration of nonsteroidal anti-inflammatory drugs. Color Dis. 2010;12: 1113-21.

7. Kuo HC, Lo MH, Hsieh KS, Guo MM, Huang YH. High-Dose Aspirin is Associated with Anemia and Does Not Confer Benefit to Disease Outcomes inKawasaki Disease. PLoS One. 2015:10:e0144603.

8. Zheng X, Yue P, Liu L, Tang C, Ma F, Zhang Y, et al. Efficacy between low and high dose aspirin for the initial treatment of Kawasaki disease: Current evidence based on a meta-analysis. PLoS One. 2019;14(5):e0217274. https:// doi.org/10.1371/journal.pone.0217274.

\section{Publisher's Note}

Springer Nature remains neutral with regard to jurisdictional claims in published maps and institutional affiliations.

\footnotetext{
Ready to submit your research? Choose BMC and benefit from:

- fast, convenient online submission

- thorough peer review by experienced researchers in your field

- rapid publication on acceptance

- support for research data, including large and complex data types

- gold Open Access which fosters wider collaboration and increased citations

- maximum visibility for your research: over $100 \mathrm{M}$ website views per year

At BMC, research is always in progress.

Learn more biomedcentral.com/submissions
} 